\title{
CPEC and Global Corridors: An Analytical Framework for Pakistan
}

\author{
Mukesh Kumar* \\ Institute of Business Management (IoBM), Karachi, Pakistan \\ Dr. Manzoor Ali Isran \\ Shaheed Zulfikar Ali Bhutto Institute of Science and Technology, Karachi, Pakistan
}

\begin{abstract}
The program of CPEC is the talk of the town as it is the landmark cooperation for the economy of Pakistan. It is the evidence of strong China-Pakistan friendship but it may test this friendship as Pakistan is going through difficult economic phase. The program encounters a vogue of debate since its inauguration due to its opportunities and associated risks. This study is an attempt to figure out a global perspective of corridors and the differences and similarities of CPEC with these global corridors. We have taken various corridors from Asia, Africa and Europe and highlighted the challenges and policy interventions of the respective corridors. This exercise allows the study to develop an analytical framework to introduce relevant soft interventions at different stages of long-term plan of CPEC.
\end{abstract}

Keywords: CPEC, Global Corridors, Regional Connectivity, Framework, policy interventions. DOI: $10.7176 / \mathrm{JESD} / 10-21-01$

Publication date: November $30^{\text {th }} 2019$

\section{Introduction}

An economic corridor is a programmatic and conceptual model for shaping physical and socio-economic outcomes. It develops an area that builds a linear agglomeration of economic activities and people along the physical backbone of transport infrastructure (Brunner, 2013). The concept of economic corridor has wide implications as it connects economic agents along a defined geography. This further creates significant links between economic hubs or nodes that are customarily centered in urban landscapes connecting extensive economic resources around the world. The benefits of economic corridor are not restricted, as it also plays its part in the regional connectivity and development. Thus, it can be comprehended only in terms of the network effects that they induce. Furthermore, improvement in the physical infrastructure accentuates the regional integration through investment (including foreign direct investment), trade, and financial market development (Bhattacharyay,2010). It also includes efforts to improve the social set up in the corridor related areas as these are essential aspects to ensure the success of the corridor.

\subsection{Evolution of a Transport Corridor}

The Asian Development Bank (ADB) introduced the idea of "economic corridor" for development across geographic regions in 1988. Meanwhile, various research efforts were made to refine the idea and to figure out its association with the other types of corridors such as transport corridors, trade corridors, development corridor, domestic trade corridors and trade corridors. Hence, the evolution of a transport corridor into an economic corridor and its transformation process at each level is defined (Hope \& Cox, 2015). 


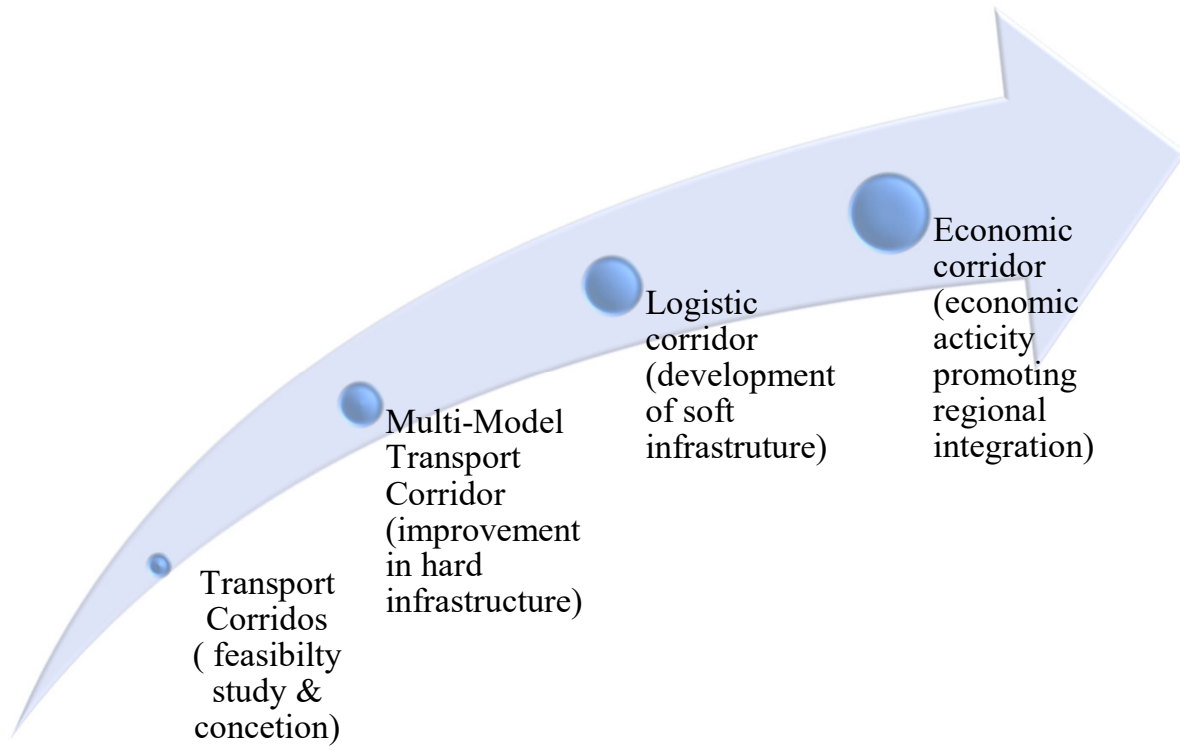

Figure 1. Evolution of a Transport Corridor into Economic Corridor; Adapted from (Hope \& Cox, 2015)

The evolution of a corridor follows a pre-determined process as it ultimately develops into economic corridor for most of the times as it is elucidated in figure 1. The figure shows that a transport corridor initiates with feasibility studies and conception of integration and results in improvement in basic infrastructure such as roads, port and highways. Latterly, improvement in hard infrastructure transforms the model in to a multi-modal transport corridor while soft infrastructure (logistics and institutions) develops it into a logistics corridor to maintain the efficiency with the passage of time. There exists an inseparable boundary between transport and economic growth as transport routes connect economic hubs within and across economies. Hence, a transport is a cluster of economically significant areas and specifically industrial one (De \& Iyengar, 2014).

An upgraded system of infrastructure also enhances living standard and reduces poverty by linking distant/remote places with economic hubs and markets bridging the development gap among the regions and provinces (Bhattacharyay, 2010). Initially, the effects are prominent in the focal areas of the corridor and subsequently growth and connectivity surges investment in other regions of the economy. However, this significant association requires a planning mechanism for multi-objective decision making (Cobacho, Caballero, Gonzalez, \& Molina, 2010) such as improvements in soft infrastructure intervention, legislation and proficiency in customs procedures, and harmonization of policies between the economies of the corridor.

\subsection{China Pakistan Economic Corridor (CPEC)}

$\mathrm{CPEC}$ is an outline of regional connectivity. It is not only a joint venture of China and Pakistan but will also ensure positive outcomes for the region including the economies of Afghanistan, Central Asian Republic, India and Iran (Butt \& Butt, 2015). The project will enhance the regional connectivity with improvement in physical infrastructure such as road, rail and air. Meanwhile, soft infrastructure initiatives will also enhance the transportation mechanism and exchange across borders. Undoubtedly, the project also has the scope for growth and social connectivity as it also undertakes various academic and cultural programs for better transformation of knowledge in the region. All the patrons of the CPEC consider it a milestone for achieving more flow of trade and business due to production and movement of energy (Miller, 2017). Therefore, win-win model of CPEC ensures more optimal businesses and enhancement of co-operation between China and Pakistan.

The vision of CPEC stimulates economic growth, bilateral relations and construction, exploring potential investment opportunities, trade, logistics, and cultural connectivity in the region. Moreover, collaborations between Pakistani and Chinese companies for energy projects, set up of export processing zones (EPZ) and industrial parks, tourism, agricultural growth, cultural exposures, poverty alleviation, and human resource development are the pivotal segments of the program.

\subsection{Objective of the Study}

The objective of this study is to figure out that comparison of CPEC with other economic corridors and come up with analytical framework. Whether the idea of corridor can be applied effectively to unlock the unrealized potential of China-Pakistan Economic Corridor (CPEC) in Pakistan. In this regard, we compare the case studies of other economic corridors with CPEC and extracted some useful similarities and dissimilarities. In broader terms, this allows to incorporate some effective policy interventions for transformative investments of CPEC in developing and emerging the economy of Pakistan. Meanwhile, we develop an analytical framework of CPEC 
based on the body of knowledge extracted from case studies of diverse global corridors. The novelty of the study is that this study aims to fill a gap in the policy initiative for CPEC by performing a mapping exercise of global corridors. More specifically, the study proceeds to identify the detail, vision, strategic upthrust, challenges and implemented policies of corridors to embed a successful transformation of CPEC as an opportunity for Pakistan given the fact that program is still in debate for its declaration as opportunity or threat (http://cpec.gov.pk/, 2018).

\section{Mapping Exercise for Corridors}

In order to understand CPEC in an extensive context, it is essential to map various global corridors as we believe that it is an instrument to create understanding the economic integration and accessibility objectives of CPEC. We first perform mapping exercise of corridors accompanied by a snapshot of the details of the corridors. Over 25 corridors have been mapped out and detailed matrix of regional corridors provides the relevant information.

To analyze the understanding of the possible rationale of these corridors the mapping of corridors considering the theme, objectives and strategic upthrust is discussed with an assessment of the economic and policy environment in which they take place.

The mapping of corridors is followed by the following selection criteria.

- The achievement of economic integration is a sine qua non condition.

- The timeline of the corridor is taken into consideration as the longer time span of the corridor is preferred for the analysis.

- An inclination is also expressed for a diversity of corridors rather focusing only on economic corridors.

- The selection of corridors is also based on some related similarities and differences so that we can perform a comparison between CPEC and other corridors in the world to avoid mitigating effects.

\subsection{Mapping of Asian Corridors}

The development of Asia has been an interesting experience from both national and regional point of view (ADB, 2015). There are variety of corridors such as development corridors, trade and transport corridors, industrial corridors, and economic corridors to develop regional connectivity and integration. Table 1 provides a quick glance on the detail of the Asian corridors.

Table 1.Detail Matrix for Corridors (Asia)

\begin{tabular}{|c|c|c|c|c|c|}
\hline $\begin{array}{c}\text { Economic } \\
\text { Corridor }\end{array}$ & Origin & Destination & Length & Country/ Region & $\begin{array}{c}\text { Regional } \\
\text { Connectivity }\end{array}$ \\
\hline $\begin{array}{l}\text { East-West } \\
\text { Economic } \\
\text { Corridor }\end{array}$ & Myanmar & Vietnam & $\begin{array}{l}1450 \\
\mathrm{~km}\end{array}$ & $\begin{array}{l}\text { Southeast Asian countries } \\
\text { Myanmar, Thailand, Laos, } \\
\text { Cambodia and Vietnam }\end{array}$ & $\begin{array}{l}\text { India- } \\
\text { Myanmar-- } \\
\text { Thailand via } \\
\text { Trilateral } \\
\text { Highway }\end{array}$ \\
\hline $\begin{array}{l}\text { North-South } \\
\text { Economic } \\
\text { Corridor } \\
\text { (NSEC) }\end{array}$ & Thailand & Lao PDR & $684 \mathrm{~km}$ & $\begin{array}{l}\text { Yunnan Province in China, } \\
\text { Shan State in Myanmar, } \\
\text { Northern Laos and Northern } \\
\text { Thailand }\end{array}$ & $\begin{array}{l}\text { Bangkok and } \\
\text { Kunming, } \\
\text { China, } \\
\text { including the } \\
\text { Laos route and } \\
\text { the Myanmar } \\
\text { route }\end{array}$ \\
\hline $\begin{array}{l}\text { Southern } \\
\text { Economic } \\
\text { Corridor } \\
\text { (SEC) }\end{array}$ & Bangkok & Dong Kralor & $\begin{array}{l}1600 \\
\mathrm{~km}\end{array}$ & Thailand-Combodia & $\begin{array}{l}\text { Bangkok and } \\
\text { Ho Chi Minh-- } \\
\text { Vung Tau }\end{array}$ \\
\hline $\begin{array}{l}\text { BCIM } \\
\text { Economic } \\
\text { Corridor }\end{array}$ & Kunming & Kolkata & $\begin{array}{l}1.65 \\
\text { million } \\
\text { sq.km }\end{array}$ & $\begin{array}{l}\text { India, China, Mayanmanr, } \\
\text { Bangladesh }\end{array}$ & $\begin{array}{l}\text { Linking the } \\
\text { ASEAN free } \\
\text { trade area }\end{array}$ \\
\hline $\begin{array}{l}\text { Sarawak } \\
\text { Corridor of } \\
\text { Renewable } \\
\text { Energy } \\
\text { (SCORE) }\end{array}$ & Similajau & $\begin{array}{l}\text { Tanjung } \\
\text { Manis, } \\
\text { Mukah }\end{array}$ & $\begin{array}{l}70,709 \\
\mathrm{~km}^{2}\end{array}$ & Malaysia & $\begin{array}{l}\text { China, India, } \\
\text { Middle East, } \\
\text { Southeast Asia }\end{array}$ \\
\hline
\end{tabular}




\begin{tabular}{|c|c|c|c|c|c|}
\hline $\begin{array}{c}\text { Economic } \\
\text { Corridor } \\
\end{array}$ & Origin & Destination & Length & Country/ Region & $\begin{array}{c}\text { Regional } \\
\text { Connectivity } \\
\end{array}$ \\
\hline $\begin{array}{l}\text { Sabah } \\
\text { Development } \\
\text { Corridor }\end{array}$ & Kota Kinabalu & Tawau & $\begin{array}{l}1348 \\
\mathrm{~km}^{2}\end{array}$ & $\begin{array}{l}\text { Kota Kinabalu, Sandakan, } \\
\text { Tawau }\end{array}$ & $\begin{array}{l}\text { Inter-regional } \\
\text { connectivity } \\
\text { and } \\
\text { international } \\
\text { linkages }\end{array}$ \\
\hline $\begin{array}{l}\text { Iskandar } \\
\text { Malaysia }\end{array}$ & Johor & Kukup & $\begin{array}{l}2,217 \\
\mathrm{~km} 2\end{array}$ & $\begin{array}{l}\text { Johor Bahru District, Kulai } \\
\text { District, Pekan Nanas, } \\
\text { Kukup }\end{array}$ & $\begin{array}{l}\text { Inter-regional } \\
\text { connectivity }\end{array}$ \\
\hline $\begin{array}{l}\text { The East } \\
\text { Coast } \\
\text { Economic } \\
\text { Region } \\
\text { (ECER) }\end{array}$ & Johor & Johor & $\begin{array}{l}66,000 \\
\text { sq-km }\end{array}$ & $\begin{array}{l}\text { Kelantan, Terengganu, } \\
\text { Pahang district of Mersing }\end{array}$ & $\begin{array}{l}\text { A gateway to } \\
\text { the Far East, } \\
\text { Asia Pacific } \\
\text { Region and } \\
\text { beyond }\end{array}$ \\
\hline $\begin{array}{l}\text { The North } \\
\text { Coast } \\
\text { Economic } \\
\text { Region } \\
\text { (NCER) }\end{array}$ & Kedah & Penang & $\begin{array}{l}66,000 \\
\text { sq. } \mathrm{km}\end{array}$ & $\begin{array}{l}\text { Kedah, Perak, Perlis, } \\
\text { Penang }\end{array}$ & $\begin{array}{l}\text { Inter-regional } \\
\text { Connectivity }\end{array}$ \\
\hline $\begin{array}{l}\text { Nanning- } \\
\text { Singapore } \\
\text { economic } \\
\text { corridor } \\
\text { (under the } \\
\text { framework of } \\
\text { MSR) }\end{array}$ & Nanning & Singapore & $5000 \mathrm{~km}$ & $\begin{array}{l}\text { China, Vietnam, Laos, } \\
\text { Cambodia, Thailand, } \\
\text { Malaysia, Singapor }\end{array}$ & $\begin{array}{l}\text { Boosting } \\
\text { tourism } \\
\text { between China } \\
\text { and the Indo- } \\
\text { China } \\
\text { Peninsula }\end{array}$ \\
\hline $\begin{array}{l}\text { International } \\
\text { North-South } \\
\text { Transport } \\
\text { Corridor }\end{array}$ & India & Russia & $7200-\mathrm{km}$ & $\begin{array}{l}\text { India, Iran, Russia, Turkey, } \\
\text { Azerbaijan, Kazakhstan, } \\
\text { Armenia, Belarus, } \\
\text { Tajikstan,Kyrgyzstan,Oman, } \\
\text { ukraine, Syria, Bulgaria }\end{array}$ & $\begin{array}{l}\text { Movement of } \\
\text { freight between } \\
\text { India, Iran, } \\
\text { Afghanistan, } \\
\text { Armenia, } \\
\text { Azerbaijan, } \\
\text { Russia, Central } \\
\text { Asia and } \\
\text { Europe }\end{array}$ \\
\hline $\begin{array}{l}\text { North-South } \\
\text { and East- } \\
\text { West } \\
\text { Corridor } \\
\text { (NS-EW) }\end{array}$ & Srinagar & Silchar & $7142 \mathrm{~km}$ & India & $\begin{array}{l}\text { Connecting } \\
\text { Srinagar with } \\
\text { Silchar through } \\
\text { Kanyakumari, } \\
\text { Kochi and } \\
\text { Porbandar } \\
\end{array}$ \\
\hline $\begin{array}{l}\text { East Coast } \\
\text { Economic } \\
\text { Corridor } \\
\text { (ECEC) }\end{array}$ & Kolkata & Kanyakumari & $\begin{array}{l}2,500 \\
\mathrm{~km}\end{array}$ & $\begin{array}{l}\text { Linking domestic } \\
\text { companies with East and } \\
\text { Southeast Asia }\end{array}$ & $\begin{array}{l}\text { West Bengal, } \\
\text { Odisha, Andhra } \\
\text { Pradesh and } \\
\text { Tamil Nadu }\end{array}$ \\
\hline $\begin{array}{l}\text { Vizag- } \\
\text { Chennai } \\
\text { Industrial } \\
\text { Corridor } \\
\text { Key part of } \\
\text { East Coast } \\
\text { Economic } \\
\text { Corridor } \\
\text { (ECEC) }\end{array}$ & Visakhapatnam & Chennai & $800 \mathrm{~km}$ & $\begin{array}{l}\text { Indian National Highway } 5 \text {, } \\
\text { the Kolkata-Chennai rail } \\
\text { route, and seven non-captive } \\
\text { operational ports }\end{array}$ & $\begin{array}{l}\text { Inter-regional } \\
\text { connectivity } \\
\text { with SAARC } \\
\text { \& ASEAN }\end{array}$ \\
\hline
\end{tabular}




\begin{tabular}{|c|c|c|c|c|c|}
\hline $\begin{array}{c}\text { Economic } \\
\text { Corridor } \\
\end{array}$ & Origin & Destination & Length & Country/ Region & $\begin{array}{c}\text { Regional } \\
\text { Connectivity } \\
\end{array}$ \\
\hline $\begin{array}{l}\text { Chennai- } \\
\text { Kanyakumari } \\
\text { Industrial } \\
\text { Corridor }\end{array}$ & $\begin{array}{l}\text { Chennai } \\
\text { (India) }\end{array}$ & $\begin{array}{l}\text { Kanyakumari } \\
\text { (India) }\end{array}$ & $655 \mathrm{~km}$ & $\begin{array}{l}23 \text { of the } 32 \text { districts of } \\
\text { Tamil Nadu }\end{array}$ & $\begin{array}{l}\text { Connecting } \\
\text { through the } \\
\text { states of } \\
\text { Thoothkudi, } \\
\text { Tirunelveli, } \\
\text { Madurai, } \\
\text { Tiruchi, } \\
\text { Cuddalore, } \\
\text { Thanjavur, } \\
\text { Pudukottai, } \\
\text { Manaparai } \\
\text { Perambalur and } \\
\text { Karaikudi }\end{array}$ \\
\hline $\begin{array}{l}\text { Odisha } \\
\text { Economic } \\
\text { Corridor }\end{array}$ & Khordha & Ganjam & $\begin{array}{l}\text { Covering } \\
20 \\
\text { districts }\end{array}$ & Odhisa (India) & $\begin{array}{l}\text { Covers the } \\
\text { entire east } \\
\text { coast running } \\
\text { from Kolkata } \\
\text { to } \\
\text { Kanyakumari }\end{array}$ \\
\hline $\begin{array}{l}\text { West Bengal } \\
\text { Economic } \\
\text { Corridor }\end{array}$ & Sonakania & Bongaon & $2241 \mathrm{~km}$ & India & $\begin{array}{l}\text { Nodes between } \\
\text { Sonakania to } \\
\text { Kolkata and } \\
\text { then Bongaon } \\
\text { to the Amritsar }\end{array}$ \\
\hline $\begin{array}{l}\text { Delhi- } \\
\text { Mumbai } \\
\text { Industrial } \\
\text { Corridor } \\
\text { Project } \\
\text { (DMIC) }\end{array}$ & Delhi & Mumbai & $1483 \mathrm{~km}$ & India & $\begin{array}{l}\text { Includes the } \\
\text { states of Dadri- } \\
\text { Noida- } \\
\text { Ghaziabad, } \\
\text { Manesar- } \\
\text { Bawal, } \\
\text { Khushkhera- } \\
\text { Bhiwadi- } \\
\text { Neemrana and } \\
\text { Jodhpur-Pali- } \\
\text { Marwar, } \\
\text { Pithampur- } \\
\text { Dhar-Mhow, } \\
\text { Ahmedabad- } \\
\text { Dholera, the } \\
\text { Shendra-Bidkin } \\
\text { Industrial Park, } \\
\text { and Dighi Port } \\
\text { Industrial Area } \\
\text { in Maharashtra }\end{array}$ \\
\hline
\end{tabular}

\section{Source: Compiled by Authors}

Out of 18 Asian corridors, only 5 have been selected. These include three transports cum economic corridors of Great Mekong Sub-region (GMS), Sabah Development Corridor (SDC) and Delhi-Mumbai Industrial Corridor (DMIC). It is pertinent to mention here that the selected corridors were designed to move progressively through physical infrastructure to economic corridor. Essentially, this will ensure wider economic benefits as these corridors have the potential to accelerate investment opportunities and economic activity including the marginalized areas along the region (Banomyomg, 2008).

2.1.1 Great Mekong Sub-Region (GMS) Corridors

Great Mekong Sub-Region (GMS) Corridors is a regional corridor initiative which intends to transform its nine transport corridors into three economic corridors. These three include East-West Economic Corridor (EWEC), North-South Economic Corridor (NSEC) and Southern Economic Corridor (SEC). These are selected for being the earliest, most comprehensive and most advanced corridor in Asia. 


\subsubsection{Sabah Development Corridor (SDC)}

The Sabah Development Corridor (SDC) is a regional development corridor initiative that took place in Malaysia. This case has been chosen for being the most ambitious project having a large component of state development and for implanting the promotion of industrial clusters and special economic zones.

2.1.3 Delhi-Mumbai Industrial Corridor (DMIC)

The Delhi-Mumbai Industrial Corridor (DMIC) is an inspirational and crowd- pleasing initiative of India to promote "Make in India" initiative and business facilitation. The project intends to define the region as investment hub with major focus on planned urbanization and freight movement and thus attracts us to include it in the case studies.

\subsection{Mapping of African Corridors}

The improvised yet resource-based continent of Africa requires an industrial development initiative to eradicate poverty and achieve sustainable growth. This requires a resource-based industrialization policy framework rooted to catalyze the growth of potential economies in Africa. There are several economies in Africa that are involved in crafting credible projects to achieve economic stability and prosperity (Mulenga, 2013). The detail matrix of the identified corridors is presented in table 2 .

Table 2. Detail Matrix for Corridors (Africa)

\begin{tabular}{|l|l|l|l|l|l|}
\hline $\begin{array}{l}\text { Economic } \\
\text { Corridor } \\
\text { Corridor }\end{array}$ & Theme & Origin & Destination & $\begin{array}{l}\text { Country/ } \\
\text { Region }\end{array}$ & Regional Connectivity \\
\hline $\begin{array}{l}\text { Trans Caprivi } \\
\text { Corridor }\end{array}$ & $\begin{array}{l}\text { Democratic } \\
\text { Republic of } \\
\text { Congo (DRC) }\end{array}$ & Zimbabwe & $\begin{array}{l}\text { Southern } \\
\text { Africa }\end{array}$ & $\begin{array}{l}\text { Two-way trade between } \\
\text { the SADC region and } \\
\text { Europe, North and South } \\
\text { America and } \\
\text { the emerging far East } \\
\text { markets }\end{array}$ \\
\hline $\begin{array}{l}\text { Trans Kalahari } \\
\text { Corridor }\end{array}$ & $\begin{array}{l}\text { Transport } \\
\text { Corridor }\end{array}$ & Botswana & Zimbabwe & Namibia & $\begin{array}{l}\text { Potential to serve two- } \\
\text { way trade between South } \\
\text { Africa, Botswana, } \\
\text { Europe, America and far } \\
\text { east }\end{array}$ \\
\hline Maputo Corridor & $\begin{array}{l}\text { Transport } \\
\text { Corridor }\end{array}$ & South Africa & Mozambique & $\begin{array}{l}\text { Gauteng, } \\
\text { Limpopo, } \\
\text { Maputo }\end{array}$ & $\begin{array}{l}\text { The shortest route of MC } \\
\text { serves as an export harbor } \\
\text { for South Africa's } \\
\text { industrial heartland in } \\
\text { Gauteng and } \\
\text { Mpumalanga }\end{array}$ \\
\hline $\begin{array}{l}\text { Zambezi Valley } \\
\text { Development } \\
\text { Corridor (ZVDC) }\end{array}$ & $\begin{array}{l}\text { Trade } \\
\text { Corridor }\end{array}$ & $\begin{array}{l}\text { Mozambic } \\
\text { Province }\end{array}$ & Malawi & Africa & $\begin{array}{l}\text { Enhancing the economic } \\
\text { potential of } \\
\text { Mozambique, Malawi and } \\
\text { Zambia }\end{array}$ \\
\hline
\end{tabular}

\section{Source: Compiled by Authors}

Here, we have identified four corridors in Table 4. For a comprehensive analysis, two have been selected. These two corridor initiatives have been launched to foster transport ad trade specifically.

\subsubsection{Trans Kalahari Corridor (TKC)}

The Trans Kalahari Corridor (TKC) originates from South Africa (SA) connecting the port of Walvis Bay to Gaborone and Gauteng and further to Zimbabwe. Considering the extension of the corridor, it further links with the coastal part of SA through Maputo Corridor.

2.2.2 Maputo Development Corridor (MDC)

Maputo Development Corridor (MDC) is a trade and transport corridor supported by the governments of South Africa (SA) and Mozambican. The MDC offers a shortest route of rail and road between Gauteng and Mpumalanga provinces of SA and connects Gaborone (Botswana) and deep-water port in Maputo. Furthermore, the private sector is responsible to ensure the full potential of MDC.

\subsection{Mapping of European Corridors}

The detail matrix of European corridors (table 3 ) reveals that there are some emerging corridor projects that foster integration and transport advancements. Precisely corridors in Europe are aimed at promoting clean fuel policies for innovative transport solutions. Moreover, removal of bottlenecks, identification of missing crosses border links; and promotion of interoperability and integration are also significant in this regard. For further analysis we discuss two initiatives out of four identified corridors. 
Table 3. Detail Matrix for Corridors (Europe)

\begin{tabular}{|c|c|c|c|c|c|}
\hline $\begin{array}{l}\text { Economic } \\
\text { Corridor }\end{array}$ & Theme & Origin & Destination & $\begin{array}{l}\text { Country/ } \\
\text { Region }\end{array}$ & $\begin{array}{c}\text { Regional } \\
\text { Connectivity }\end{array}$ \\
\hline $\begin{array}{l}\text { East-West } \\
\text { Transport } \\
\text { corridor }\end{array}$ & $\begin{array}{l}\text { Transport } \\
\text { Corridor }\end{array}$ & China & Denmark & $\begin{array}{l}\text { Denmark, Sweden, } \\
\text { Germany,Lithuania,Beralus, } \\
\text { Russia, Ukraine, China }\end{array}$ & \\
\hline $\begin{array}{l}\text { Baltic- } \\
\text { Adriatic } \\
\text { Corri5dor }\end{array}$ & $\begin{array}{l}\text { Transport } \\
\text { Corridor }\end{array}$ & $\begin{array}{l}\text { Gdansk } \\
\text { Głowny } \\
\text { Railway } \\
\text { station }\end{array}$ & $\begin{array}{l}\text { Vienna - } \\
\text { Graz } \\
\text { (Southern } \\
\text { Railway) }\end{array}$ & Central Europe & $\begin{array}{l}\text { Transport links } \\
\text { between } \\
\text { Europe and } \\
\text { global markets } \\
\text { (Eastern } \\
\text { Med/SE Asia) }\end{array}$ \\
\hline $\begin{array}{l}\text { Southeast } \\
\text { Transport } \\
\text { Axis } \\
\text { (SETA) } \\
\text { Corridor }\end{array}$ & $\begin{array}{l}\text { Trade \& } \\
\text { Transport } \\
\text { Corridor }\end{array}$ & $\begin{array}{l}\text { Central } \\
\text { Europe }\end{array}$ & $\begin{array}{l}\text { Northern } \\
\text { Adriatic } \\
\text { ports }\end{array}$ & $\begin{array}{l}\text { Croatia, Bosnia, Herzegovina, } \\
\text { Serbia, Kosovo, Albana }\end{array}$ & \\
\hline $\begin{array}{l}\text { Transport } \\
\text { Corridor } \\
\text { Europe- } \\
\text { Caucasus- } \\
\text { Asia } \\
\text { (TRACEA) }\end{array}$ & $\begin{array}{l}\text { Trade \& } \\
\text { Transport } \\
\text { Corridor }\end{array}$ & Armenia & $\begin{array}{l}\text { European } \\
\text { Union States }\end{array}$ & $\begin{array}{l}\text { Armenia, Azerbaijan, Bulgaria, } \\
\text { Georgia, Kazakhstan, } \\
\text { Kyrgyzstan, Iran, Moldova, } \\
\text { Romania, } \\
\text { Turkey,Ukraine ,Uzbekistan, } \\
\text { Tajikistan,Turkmenistan \& } 28 \\
\text { member states of the EU }\end{array}$ & \\
\hline
\end{tabular}

\section{Source: Compiled by Authors}

2.3.1 Baltic-Adriatic Corridor

Baltic-Adriatic Corridor is a significant axis of European road and railway. The industrialized areas are central to link the Baltic with Adriatic Sea between Southern Poland and Northern Italy. It is a work in progress comprising projects of railway routes in Austria and other cross border economies (Wendt \& Wiskulski, 2012).

\subsubsection{South East Transport Axis (SETA)}

South East Transport Axis (SETA) is a trade and transport corridor for better accessibility in South East Europe. The corridor basically revolves around the concept of "Green Corridor"to ensure environment friendly freight between Central and South East European regions. Moreover, to improve the infrastructure facilities the corridor looks for more access to alternate financing options within the partner regions.

The detailed matrix of corridors revealed that regional differences are vibrant among these corridors based on geographical significance, theme of the corridor, destination and covered length involvement of patron and conveners for better connectivity and regional integration.

\section{CPEC and Global Corridors}

This section briefly investigates that how CPEC is similar the international corridors and meanwhile, what are the key factors that differentiate the project of CPEC from other corridors in Asia, Africa and Europe. 
Table 4. Transport Matrix for Corridors

\begin{tabular}{|c|c|c|c|c|c|c|}
\hline Economic Corridor & Road & Port & Rail & Air & Utilities & Pipeline \\
\hline \multicolumn{7}{|c|}{ Asia } \\
\hline China Pakistan Economic Corridor & $\checkmark$ & $\checkmark$ & $\checkmark$ & & & \\
\hline East-West Economic Corridor (GMS) & $\checkmark$ & & $\checkmark$ & & & \\
\hline North-South Economic Corridor (NSEC) & $\checkmark$ & $\checkmark$ & $\checkmark$ & & & \\
\hline Southern Economic Corridor (SEC) & $\checkmark$ & $\checkmark$ & & & & \\
\hline BCIM Economic Corridor & $\checkmark$ & $\checkmark$ & $\checkmark$ & & & \\
\hline Sarawak Corridor of Renewable Energy (SCORE) & $\checkmark$ & $\checkmark$ & & $\checkmark$ & $\checkmark$ & \\
\hline Sabah Development Corridor & $\checkmark$ & & $\checkmark$ & $\checkmark$ & $\checkmark$ & \\
\hline Iskandar Malaysia & $\checkmark$ & $\checkmark$ & $\checkmark$ & $\checkmark$ & & \\
\hline The East Coast Economic Region (ECER) & $\checkmark$ & $\checkmark$ & $\checkmark$ & $\checkmark$ & & \\
\hline \multicolumn{7}{|l|}{ The North Coast Economic Region (NCER) } \\
\hline $\begin{array}{l}\text { Nanning-Singapore economic corridor (under the } \\
\text { framework of MSR) }\end{array}$ & $\checkmark$ & & $\checkmark$ & & & $\checkmark$ \\
\hline International North-South Transport Corridor & $\checkmark$ & $\checkmark$ & $\checkmark$ & & & \\
\hline North-South and East-West Corridor (NS-EW) & $\checkmark$ & & & & & \\
\hline \multicolumn{7}{|l|}{ East Coast Economic Corridor (ECEC) } \\
\hline \multicolumn{7}{|l|}{$\begin{array}{l}\text { Vizag-Chennai Industrial Corridor } \\
\text { (ECEC) }\end{array}$} \\
\hline Chennai-Kanyakumari Industrial Corridor & & $\checkmark$ & $\checkmark$ & & & \\
\hline Odisha Economic Corridor & $\checkmark$ & $\checkmark$ & & & & \\
\hline West Bengal Economic Corridor & $\checkmark$ & & & & & \\
\hline Delhi-Mumbai Industrial Corridor Project (DMIC) & $\checkmark$ & $\checkmark$ & & $\checkmark$ & & \\
\hline \multicolumn{7}{|l|}{$\begin{array}{ll} & \text { Africa } \\
\end{array}$} \\
\hline Trans Caprivi Corridor & $\checkmark$ & $\checkmark$ & & & & \\
\hline Trans Kalahari Corridor & $\checkmark$ & $\checkmark$ & $\checkmark$ & $\vee$ & & \\
\hline Maputo Corridor & $\checkmark$ & $\checkmark$ & $\checkmark$ & & $\checkmark$ & $\checkmark$ \\
\hline Zambezi Valley Development Corridor (ZVDC) & $\checkmark$ & & $\checkmark$ & & & \\
\hline \multicolumn{7}{|c|}{ Europe } \\
\hline East -West Transport corridor & $\checkmark$ & $\checkmark$ & & & & \\
\hline Baltic-Adriatic Corridor & & & $\checkmark$ & & & \\
\hline South East Transport Axis (SETA) Corridor & & & $\checkmark$ & & & \\
\hline Transport Corridor Europe-Caucasus-Asia (TRACEA) & $\checkmark$ & $\checkmark$ & $\checkmark$ & & & \\
\hline
\end{tabular}

\section{Source: Compiled by Authors}

Table 4 summarizes various transport modes of the corridors. The tables show that almost every corridor including CPEC covers road and port of the host country while other modes- railway; air, utilities and pipelines are also part of these corridors. This highlights the argument given by (Coşar \& Demir, 2016) that poor quality of transport infrastructure in developing economies is the key impediment in accessing international access to international markets.

Furthermore, inclusion of ports in a corridor highlights the strategic significance of ports especially for the land locked areas (Terrill, 2018). It is also similar for CPEC as Pakistan is going to facilitate China by providing the port services through Gawadar port for their western China region. Turning to the case of Africa, it is obvious that poor infrastructure demands more roads and railway tracks. Instead of relying on roads and port, European corridors are more inclined towards market diversification and thus development of railway and other alternative transport mode (Martín, 2011). CPEC also include projects to improve the existing infrastructure and railway network and intends to further diversify it in future. 


\subsection{CPEC and Asian Corridors}

Table 5 explains the respective vision and strategic upthrust of CPEC and other corridors. This matrix basically assesses to figure out the similarities and differences between CPEC and other corridors in Asia.

Table 5. Vision and Strategic Up thrust Matrix for Corridors in Asia

\begin{tabular}{|c|c|c|c|}
\hline $\begin{array}{l}\text { Economic } \\
\text { Corridor }\end{array}$ & Theme & Vision & $\begin{array}{l}\text { Strategic } \\
\text { Up thrust }\end{array}$ \\
\hline $\begin{array}{l}\text { China } \\
\text { Pakistan } \\
\text { Economic } \\
\text { Corridor } \\
\text { (CPEC) }\end{array}$ & $\begin{array}{l}\text { Economic } \\
\text { Corridor }\end{array}$ & $\begin{array}{l}\text { To improve the lives of } \\
\text { people of Pakistan and } \\
\text { China by building an } \\
\text { economic corridor } \\
\text { promoting bilateral } \\
\text { connectivity }\end{array}$ & $\begin{array}{l}\text { Energy cooperation, agricultural } \\
\text { development \& poverty alleviation, } \\
\text { cooperation \& people to people } \\
\text { communication }\end{array}$ \\
\hline $\begin{array}{l}\text { East-West } \\
\text { Economic } \\
\text { Corridor } \\
\text { (EWEC) }\end{array}$ & $\begin{array}{l}\text { Economic } \\
\text { Corridor }\end{array}$ & $\begin{array}{l}\text { To bring prosperity and } \\
\text { well-being to all people in } \\
\text { the corridor area }\end{array}$ & $\begin{array}{l}\text { Connectivity, social and } \\
\text { environmental sustainability, } \\
\text { empowerment of private sector, } \\
\text { poverty reduction }\end{array}$ \\
\hline $\begin{array}{l}\text { North-South } \\
\text { Economic } \\
\text { Corridor } \\
\text { (NSEC) }\end{array}$ & $\begin{array}{l}\text { Economic } \\
\text { Corridor }\end{array}$ & 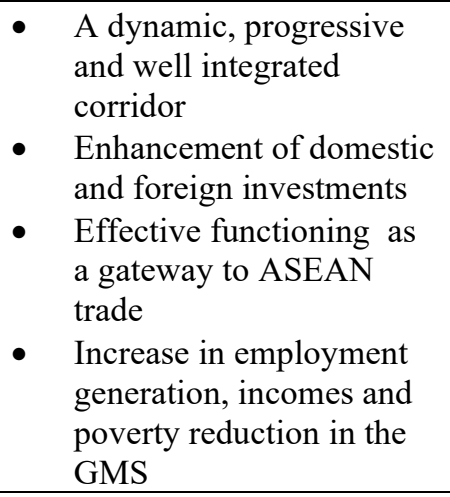 & $\begin{array}{l}\text { Conventional measures to deal with } \\
\text { social and environmental concerns, } \\
\text { Strengthening infrastructure and } \\
\text { facilities, cross border trade and } \\
\text { transport, investment in key sectors } \\
\text { and industries ,expansion of public } \\
\text { private partnership, establishment and } \\
\text { enhancement of institutional } \\
\text { mechanism of NSEC }\end{array}$ \\
\hline $\begin{array}{l}\text { Southern } \\
\text { Economic } \\
\text { Corridor } \\
\text { (SEC) }\end{array}$ & $\begin{array}{l}\text { Economic } \\
\text { Corridor }\end{array}$ & $\begin{array}{l}\text { A prosperous and } \\
\text { dynamic corridor that } \\
\text { improves the well-being } \\
\text { of the people } \\
\text { - Inclusive sustainable } \\
\text { development }\end{array}$ & $\begin{array}{l}\text { Strengthen infrastructure and } \\
\text { connectivity, trade facilitation, } \\
\text { enhancing investment opportunities, } \\
\text { social and environment concerns, } \\
\text { private sector participation }\end{array}$ \\
\hline $\begin{array}{l}\text { BCIM } \\
\text { Economic } \\
\text { Corridor }\end{array}$ & $\begin{array}{l}\text { Economic } \\
\text { Corridor }\end{array}$ & $\begin{array}{l}\text { Development of supply } \\
\text { chains based on } \\
\text { comparative advantage } \\
\text { Transforming } \\
\text { comparative advantages } \\
\text { into competitive } \\
\text { advantages } \\
\text { closer people to people } \\
\text { contact }\end{array}$ & $\begin{array}{l}\text { Increase in investment, infrastructure } \\
\text { development, joint exploration and } \\
\text { development of mineral, water, and } \\
\text { other natural resources }\end{array}$ \\
\hline $\begin{array}{l}\text { Sarawak } \\
\text { Corridor of } \\
\text { Renewable } \\
\text { Energy } \\
\text { (SCORE) }\end{array}$ & $\begin{array}{l}\text { Development } \\
\text { corridor }\end{array}$ & $\begin{array}{l}\text { High income and } \\
\text { advanced state }\end{array}$ & $\begin{array}{l}\text { Building momentum to trigger } \\
\text { development, infrastructure projects }\end{array}$ \\
\hline $\begin{array}{l}\text { Sabah } \\
\text { Development } \\
\text { Corridor }\end{array}$ & $\begin{array}{l}\text { Development } \\
\text { Corridor }\end{array}$ & $\begin{array}{l}\text { Wealth diversity } \\
\text { Harnessing unity in } \\
\text { diversity for wealth } \\
\text { creation and social well } \\
\text { being }\end{array}$ & $\begin{array}{l}\text { Promoting harmony in the state } \\
\text { regardless of race or religion, creating } \\
\text { job opportunities, more technology- } \\
\text { savvy state, making the state a } \\
\text { comfortable state for living }\end{array}$ \\
\hline $\begin{array}{l}\text { Iskandar } \\
\text { Malaysia }\end{array}$ & $\begin{array}{l}\text { Development } \\
\text { Corridor }\end{array}$ & $\begin{array}{l}\text { To boost the physical and } \\
\text { economic development of } \\
\text { the state }\end{array}$ & $\begin{array}{l}\text { Immediate implementation of } \\
\text { Strategic Economic Thrust (SET) for } \\
\text { future growth in long term (2005- } \\
2025)\end{array}$ \\
\hline
\end{tabular}




\begin{tabular}{|c|c|c|c|}
\hline $\begin{array}{l}\text { Economic } \\
\text { Corridor }\end{array}$ & Theme & Vision & $\begin{array}{c}\text { Strategic } \\
\text { Up thrust }\end{array}$ \\
\hline $\begin{array}{l}\text { The East } \\
\text { Coast } \\
\text { Economic } \\
\text { Region } \\
\text { (ECER) }\end{array}$ & $\begin{array}{l}\text { Development } \\
\text { Corridor }\end{array}$ & $\begin{array}{l}\text { To be a developed region } \\
\text { by } 2020 \text { fast-forwarding }\end{array}$ & $\begin{array}{l}\text { Moving up the economy through } \\
\text { value chain, raising capacity for } \\
\text { knowledge and innovation, addressing } \\
\text { socio-economic inequalities, } \\
\text { improvement in standard and } \\
\text { sustainability of the quality of life, } \\
\text { strengthening the implementation } \\
\text { and institutional capacity }\end{array}$ \\
\hline $\begin{array}{l}\text { The North } \\
\text { Coast } \\
\text { Economic } \\
\text { Region } \\
\text { (NCER) }\end{array}$ & $\begin{array}{l}\text { Development } \\
\text { Corridor }\end{array}$ & $\begin{array}{l}\text { - } \text { Growth with social equity } \\
\text { - } \quad \text { To maximize the } \\
\text { economic potential } \\
\text { - To minimize the income } \\
\text { gap between the different } \\
\text { regions in Malaysia }\end{array}$ & $\begin{array}{l}\text { Socio-economic progress, knowledge } \\
\text { based economy, increase in per capita } \\
\text { income }\end{array}$ \\
\hline $\begin{array}{l}\text { Nanning- } \\
\text { Singapore } \\
\text { economic } \\
\text { corridor } \\
\text { (under the } \\
\text { framework of } \\
\text { MSR) }\end{array}$ & $\begin{array}{l}\text { Economic } \\
\text { Corridor }\end{array}$ & $\begin{array}{l}\text { Good relationship with } \\
\text { neighboring economies } \\
\text { Development across the } \\
\text { ASEAN-China Free } \\
\text { Trade Area }\end{array}$ & $\begin{array}{l}\text { Investment in China-ASEAN } \\
\text { tourism, trade, cultural and social } \\
\text { exchange, distribution of labor in the } \\
\text { industrial chains }\end{array}$ \\
\hline $\begin{array}{l}\text { International } \\
\text { North-South } \\
\text { Transport } \\
\text { Corridor }\end{array}$ & $\begin{array}{l}\text { Transport } \\
\text { Corridor }\end{array}$ & $\begin{array}{l}\text { Increase in trade } \\
\text { connectivity between } \\
\text { major cities such as } \\
\text { Mumbai, Moscow, } \\
\text { Tehran, Baku, Bandar } \\
\text { Abbas, Astrakhan, } \\
\text { Bandar Anzali }\end{array}$ & $\begin{array}{l}\text { Cost reductions in terms of time and } \\
\text { money over the recent and traditional } \\
\text { route }\end{array}$ \\
\hline $\begin{array}{l}\text { North-South } \\
\text { and East- } \\
\text { West } \\
\text { Corridor } \\
\text { (NS-EW) }\end{array}$ & $\begin{array}{l}\text { Transport } \\
\text { Corridor }\end{array}$ & $\begin{array}{l}\text { To ease chronic capacity } \\
\text { restrictions by upgrading } \\
\text { key routes of the national } \\
\text { highway network }\end{array}$ & $\begin{array}{l}\text { Promotion of economic growth with } \\
\text { the easier and less costly movement of } \\
\text { goods and people }\end{array}$ \\
\hline $\begin{array}{l}\text { East Coast } \\
\text { Economic } \\
\text { Corridor } \\
\text { (ECEC) }\end{array}$ & $\begin{array}{l}\text { Economic } \\
\text { Corridor }\end{array}$ & $\begin{array}{l}\text { To play a vital part in } \\
\text { amalgamating the large } \\
\text { domestic market, } \\
\text { To integrate a dynamic } \\
\text { Indian economy through } \\
\text { global value chains of } \\
\text { Southeast and East Asia }\end{array}$ & $\begin{array}{l}\text { Promoting industry integration and } \\
\text { synergy, infrastructure development, } \\
\text { logistics, urbanization, focusing } \\
\text { industrial production clusters, urban } \\
\text { centers, international gateways, } \\
\text { formation of efficient multimodal } \\
\text { transport network }\end{array}$ \\
\hline $\begin{array}{l}\text { Vizag- } \\
\text { Chennai } \\
\text { Industrial } \\
\text { Corridor } \\
\text { Key part of } \\
\text { East Coast } \\
\text { Economic } \\
\text { Corridor } \\
\text { (ECEC) }\end{array}$ & $\begin{array}{l}\text { Transport } \\
\text { Corridor }\end{array}$ & $\begin{array}{l}\text { - To leverage the maritime } \\
\text { privilege of industries } \\
\text { To promote } \\
\text { industrialization }\end{array}$ & $\begin{array}{l}\text { Identification of international markets } \\
\text { at provincial level, development and } \\
\text { participation in collaborative } \\
\text { international trade, investment } \\
\text { initiatives with common interests }\end{array}$ \\
\hline $\begin{array}{l}\text { Chennai- } \\
\text { Kanyakumari } \\
\text { Industrial } \\
\text { Corridor }\end{array}$ & $\begin{array}{l}\text { Industrial } \\
\text { Corridor }\end{array}$ & $\begin{array}{l}\text { To unlock the potential to } \\
\text { accelerate manufacturing } \\
\text { growth in the state of } \\
\text { Tamil Nadu }\end{array}$ & $\begin{array}{l}\text { Managing the accelerated growth of } \\
\text { mobbed cities, acquiring high class } \\
\text { urban amenities }\end{array}$ \\
\hline
\end{tabular}




\begin{tabular}{|c|c|c|c|}
\hline $\begin{array}{l}\text { Economic } \\
\text { Corridor }\end{array}$ & Theme & Vision & $\begin{array}{l}\text { Strategic } \\
\text { Up thrust }\end{array}$ \\
\hline $\begin{array}{l}\text { Odisha } \\
\text { Economic } \\
\text { Corridor }\end{array}$ & $\begin{array}{l}\text { Economic } \\
\text { Corridor }\end{array}$ & $\begin{array}{l}\text { To play a crucial role in } \\
\text { transporting various } \\
\text { goods }\end{array}$ & $\begin{array}{l}\text { Increase in investment opportunities, } \\
\text { synchronized industrial and urban } \\
\text { settlements institutional framework } \\
\text { for implementation }\end{array}$ \\
\hline $\begin{array}{l}\text { West Bengal } \\
\text { Economic } \\
\text { Corridor }\end{array}$ & $\begin{array}{l}\text { Economic } \\
\text { Corridor }\end{array}$ & $\begin{array}{ll}\text { - } & \text { To promote sub regional } \\
& \text { economic activities } \\
\text { - } & \text { Poverty reduction } \\
\text { - } & \text { Trade facilitation } \\
\text { - } & \text { Removal of critical } \\
& \text { capacity constraints } \\
\text { through improvement in } \\
\text { transport efficiency }\end{array}$ & $\begin{array}{l}\text { Sub-regional connectivity, } \\
\text { rehabilitation of rural communities } \\
\text { through better access to markets, } \\
\text { hospitals, schools, employment and } \\
\text { social services }\end{array}$ \\
\hline $\begin{array}{l}\text { Delhi- } \\
\text { Mumbai } \\
\text { Industrial } \\
\text { Corridor } \\
\text { (DMIC) }\end{array}$ & $\begin{array}{l}\text { Industrial } \\
\text { Corridor }\end{array}$ & $\begin{array}{l}\text { To connect investment } \\
\text { nodes to ensure impetus } \\
\text { to 'Make in India' } \\
\text { initiative } \\
\text { - } \quad \text { To facilitate the business } \\
\text { opportunities } \\
\text { To remove hiccups in } \\
\text { land acquisitions for } \\
\text { industry set up } \\
\text { To provide fast, cheap } \\
\text { and efficient } \\
\text { transportation }\end{array}$ & $\begin{array}{l}\text { Industrial development, investments } \\
\text { in industries, provision of stable } \\
\text { environment to businessman for more } \\
\text { investments, enhancement of export } \\
\text { and employment potential }\end{array}$ \\
\hline
\end{tabular}

\section{Source: Compiled by Authors}

Nearly all corridors possess similar objectives same as CPEC. These include enhancing regional connectivity, infrastructure development; trade facilitation; poverty reduction and social and cultural integration and so on. (Roberts, Melecky, Bougna, \& Xu, 2018) However, it is pertinent to mention here that theses corridors seek different goals than CPEC.

For instance, EWEC is more oriented towards social and environmental sustainability and empowerment of private sector. The Vizag-Chennai Industrial Corridor (VCIC) is a project to be started soon, stresses on more access to international markets at provincial level (ADB, 2015).

In the short-run, there is no any significant initiative under CPEC offering institutional capacity, provision of stable environment to businessmen for more investments, synchronized industrial and urban settlements, institutional framework for implementation, social and environmental sustainability and empowerment of private sector. All these aspects create challenges for the success of CPEC in Pakistan. It is observed that while establishing economic corridors, the success of corridor closely depends on policy reform, capacity development, and the strengthening of institutions (De \& Iyengar, 2014).

\subsection{CPEC and African Corridors}

Table 6 reveals that the continent of Africa is more interested in developing trade and transport corridor as the infrastructure facilities in Africa are not only poor but also the region is lagged behind in terms of trade and regional connectivity. These characteristics of African corridors are in in line with CPEC. However, CPEC is different in a sense that African corridors are developed to utilize the idle natural resources for the development of the economies while there no such intuition in case of CPEC. The African corridors heavily rely unlocking its mining and agriculture potential such as Trans Kalahari Corridor (TKC) and Zambezi Valley Development Corridor (ZVDC). Despite the fact that Pakistan is enriched with natural resources and agricultural potential, there is yet no project in CPEC to develop the natural resources and agriculture sectors of Pakistan. However long-term plan of CEPC reflects development of agriculture and natural resources clusters of Pakistan. 
Table 6. Vision and Strategic Up thrust Matrix for Corridors in Africa

\begin{tabular}{|c|c|c|c|}
\hline Corridors & Theme & Vision & Strategic Upthrust \\
\hline $\begin{array}{l}\text { Trans } \\
\text { Caprivi } \\
\text { Corridor }\end{array}$ & $\begin{array}{l}\text { Transport } \\
\text { Corridor }\end{array}$ & $\begin{array}{l}\text { - To develop the infrastructure } \\
\text { facilities in the region }\end{array}$ & $\begin{array}{l}\text { Trade and transport facilitation } \\
\text { with improved logistic set up }\end{array}$ \\
\hline $\begin{array}{l}\text { Trans } \\
\text { Kalahari } \\
\text { Corridor } \\
\text { (TKC) }\end{array}$ & $\begin{array}{l}\text { Transport } \\
\text { Corridor }\end{array}$ & $\begin{array}{l}\text { - To improve and facilitate trade } \\
\text { and transport through better } \\
\text { infrastructure } \\
\text { - To ensure harmonization of } \\
\text { conflicting regulations and } \\
\text { polices } \\
\text { Providing quality services at } \\
\text { minimal costs, and sSp:increasing } \\
\text { competitiveness }\end{array}$ & $\begin{array}{l}\text { Harmonization of conflicting } \\
\text { policies and regulations of the } \\
\text { three economies, ensuring an } \\
\text { integrated transport and trade } \\
\text { system in accordance with better } \\
\text { logistics services and travelling } \\
\text { system }\end{array}$ \\
\hline $\begin{array}{l}\text { Maputo } \\
\text { Development } \\
\text { Corridor }\end{array}$ & $\begin{array}{l}\text { Trade \& } \\
\text { Transport } \\
\text { Corridor }\end{array}$ & $\begin{array}{l}\text { To establish developmental } \\
\text { alliance between the Maputo } \\
\text { port and the Gauteng province } \\
\text { of South Africa }\end{array}$ & $\begin{array}{l}\text { Development of the most highly } \\
\text { industrialized and productive } \\
\text { regions of Southern Africa such } \\
\text { as the Mpumalanga, Gauteng, } \\
\text { and Limpopo Provinces to } \\
\text { Mozambique }\end{array}$ \\
\hline $\begin{array}{l}\text { Zambezi } \\
\text { Valley } \\
\text { Development } \\
\text { Corridor } \\
\text { (ZVDC) }\end{array}$ & $\begin{array}{l}\text { Transport } \\
\text { Corridor }\end{array}$ & $\begin{array}{l}\text { - To unlock economic potential } \\
\text { of mining and agriculture in } \\
\text { Mozambique }\end{array}$ & $\begin{array}{l}\text { Enhancement of coal an } \\
\text { hydropower energy for } \\
\text { industries, promotion of more } \\
\text { production and thus } \\
\text { consumption of residents }\end{array}$ \\
\hline
\end{tabular}

\section{Source: Compiled by Authors}

\subsection{CPEC and European Corridors}

The vision of CPEC and European corridors revolves around strengthening economic relations, trade and transport in the region. In Europe, the European Union (EU) is seeking to enter new markets offering the EU a renewed economic influence in the region. Therefore, the corridors in Europe are intended to develop more cooperation, low freight costs and promotion of knowledge based economies. This is the main thing that differentiates CPEC from European corridors.

Table 7: Vision and Strategic Up thrust Matrix for Corridors in Europe

\begin{tabular}{|l|l|l|l|}
\hline \multicolumn{1}{|c|}{$\begin{array}{c}\text { Economic } \\
\text { Corridor }\end{array}$} & Theme & \multicolumn{1}{c|}{ Vision } & \multicolumn{1}{c|}{ Strategic Upthrust } \\
\hline $\begin{array}{l}\text { East -West } \\
\text { corridor }\end{array}$ & $\begin{array}{l}\text { Transport } \\
\text { Corridor }\end{array}$ & $\begin{array}{l}\text { To form an effective } \\
\text { transnational supply chain } \\
\text { To provide different means } \\
\text { of transportation and } \\
\text { logistics services }\end{array}$ & $\begin{array}{l}\text { Achievement of synergy, and cooperation } \\
\text { between different } \\
\text { stakeholders within the global supply chain }\end{array}$ \\
\hline $\begin{array}{l}\text { Baltic-Adriatic } \\
\text { Corridor }\end{array}$ & $\begin{array}{l}\text { Transport } \\
\text { Corridor }\end{array}$ & $\begin{array}{l}\text { To provide support to } \\
\text { Central Europe regions } \\
\text { To improve accessibility of } \\
\text { transportation between } \\
\text { Adriatic and Baltic Sea } \\
\text { along the North South axis }\end{array}$ & $\begin{array}{l}\text { Low freight costs, safety and security, } \\
\text { provision of top logistics requirements } \\
\text { through tracking and tracing, assurance } \\
\text { reliable and guaranteed departures of } \\
\text { freights across borders, warehousing } \\
\text { facilities for fresh food, reload facilities }\end{array}$ \\
\hline $\begin{array}{l}\text { South East } \\
\text { Transport Axis } \\
\text { (SETA) Corridor }\end{array}$ & $\begin{array}{l}\text { Trade \& } \\
\text { Transport }\end{array}$ & $\begin{array}{l}\text { To build efficient railways } \\
\text { links between the } \\
\text { landlocked areas of Central } \\
\text { Europe and the Northern } \\
\text { Adriatic port }\end{array}$ & $\begin{array}{l}\text { Focus on upgrading the existing rail } \\
\text { infrastructure, moderate investment costs } \\
\text { for project, connection various means of } \\
\text { transport }\end{array}$ \\
\hline $\begin{array}{l}\text { Transport } \\
\text { Corridor Europe- } \\
\text { Caucasus-Asia } \\
\text { (TRACEA) }\end{array}$ & $\begin{array}{l}\text { Transport } \\
\text { \& Trade } \\
\text { Corridor }\end{array}$ & $\begin{array}{l}\text { To strengthen economic } \\
\text { relations, trade and transport } \\
\text { in the regions of the Black } \\
\text { Sea basin, South Caucasus } \\
\text { and Central Asia }\end{array}$ & $\begin{array}{l}\text { Cooperation, progressive integration } \\
\text { through mutual interests, Set up of } \\
\text { transport networks, access to EU markets, } \\
\text { international legal and regulatory outlines }\end{array}$ \\
\hline
\end{tabular}

\section{Source: Compiled by Authors}


The current projects included in CPEC cover only cross-border trade between China and Pakistan. New markets and regions for connectivity under CPEC are yet to be explored in terms of trade and market diversification for Pakistan. Meanwhile, the international lobby of USA, India and Afghanistan is persistently opposing the project of CPEC blocking the economic integration perspective of CPEC (Abid \& Ashfaq, 2015).

\section{Challenges and Policy Interventions of Selected Corridors}

\subsection{Policy Interventions of Selected Asian Corridors}

Table 8 provides a brief view of the policy interventions in Asia to cope with the challenges faced by the management authorities of the corridor.

Table 8. Matrix of Policy Interventions of Asian Corridors

\begin{tabular}{|c|c|c|}
\hline Corridor & Challenges & Policy Interventions \\
\hline $\begin{array}{l}\text { East-West } \\
\text { Economic } \\
\text { Corridor } \\
\text { (EWEC) }\end{array}$ & $\begin{array}{ll}\text { - } & \text { Integrate immigration and customs } \\
\text { check post (India to Vietnam) } \\
\text { - } \\
\text { Incomplete cross border and } \\
\text { multimodal infrastructure network } \\
\text { - } \quad \text { Partially completed feeder road } \\
\text { network connecting production and } \\
\text { hub } \\
\text { - Inefficient interoperability among } \\
\text { different modes of transport }\end{array}$ & $\begin{array}{l}\text { Provision of e-visas to foreign } \\
\text { tourists } \\
\text { - } \quad \begin{array}{l}\text { Elimination of tariffs and non-tariff } \\
\text { barriers }\end{array} \\
\text { - } \quad \begin{array}{l}\text { cross-border transport agreement } \\
\text { - Simplification of logistics and } \\
\text { customs procedures }\end{array}\end{array}$ \\
\hline $\begin{array}{l}\text { North-South } \\
\text { Economic } \\
\text { Corridor } \\
\text { (NSEC) }\end{array}$ & $\begin{array}{ll}\text { - } & \text { High transportation cost } \\
\text { - } & \text { Illegal movements across borders } \\
\text { (human trafficking) } \\
\text { - } & \text { Equity issues } \\
\text { - } & \text { Environmental problems income } \\
\text { disparities }\end{array}$ & $\begin{array}{l}\text { Encouraged participation of local } \\
\text { authorities in the corridor } \\
\text { - } \quad \begin{array}{l}\text { Export diversification for poor } \\
\text { economies }\end{array} \\
\text { - } \quad \text { Continuation of Transport and Trade } \\
\text { Facilitation (TTF) } \\
\text { Facilitation of logistics services, } \\
\text { Development of border and corridor } \\
\text { towns } \\
\text { - Investment promotion and enterprise } \\
\text { development, } \\
\text { Improvement of access to and from } \\
\text { adjacent areas } \\
\text { Multimodal transport } \\
\text { development }\end{array}$ \\
\hline $\begin{array}{l}\text { Southern } \\
\text { Economic } \\
\text { Corridor } \\
\text { (SEC) }\end{array}$ & $\begin{array}{l}\text { - } \\
\text { Bllowed but restricted trade } \\
\text { Border trade barriers } \\
\text { Failure of both Thai and Cambodia } \\
\text { public authorities in trade } \\
\text { facilitation } \\
\text { - } \quad \text { Non issuance of truck and bus } \\
\text { permits } \\
\text { - Soft infrastructure issues }\end{array}$ & $\begin{array}{l}\text { - Improvement in cross-border } \\
\text { facilities } \\
\text { - Encouragement of TTF } \\
\text { - Enhancement of logistics services }\end{array}$ \\
\hline $\begin{array}{l}\text { Sabah } \\
\text { Development } \\
\text { Corridor }\end{array}$ & $\begin{array}{l}\text { Co-ordination of multiple agencies } \\
\text { within the authority } \\
\text { - } \quad \text { Monitoring and close association } \\
\text { with implementing bodies for } \\
\text { better quality of infrastructure } \\
\text { - Assurance to investors }\end{array}$ & $\begin{array}{l}\text { Proper designation of land for } \\
\text { industrial, agricultural, commercial, } \\
\text { residential etc. } \\
\text { - } \begin{array}{l}\text { Detailed market analysis to bring } \\
\text { together industry players and }\end{array} \\
\text { catalysts } \\
\text { - } \begin{array}{l}\text { Balancing expediency against good } \\
\text { governance }\end{array} \\
\text { - Specific fiscal incentive packages } \\
\text { for investors }\end{array}$ \\
\hline $\begin{array}{l}\text { Delhi- } \\
\text { Mumbai } \\
\text { Industrial }\end{array}$ & $\begin{array}{ll}\text { - } & \text { Land acquisition issues } \\
\text { - } & \text { Abandoned power projects } \\
\text { - } & \text { Slow pace of project }\end{array}$ & $\begin{array}{l}\text { - Smooth movement of goods Capital } \\
\text { and investment initiatives } \\
\text { - } \quad \text { Specialized satellite cities }\end{array}$ \\
\hline
\end{tabular}




\begin{tabular}{|c|c|c|}
\hline Corridor & Challenges & Policy Interventions \\
\hline $\begin{array}{l}\text { Corridor } \\
\text { Project } \\
\text { (DMIC) }\end{array}$ & - Weak corridor nodes & $\begin{array}{ll}\text { - } & \text { Integrated through a web } \\
\text { - } & \text { of Transportation arteries } \\
\text { - } & \text { promotion of high tech and } \\
\text { - } & \text { mowledge based industry } \\
\text { mix }\end{array}$ \\
\hline
\end{tabular}

\section{Source: Compiled by Authors}

Despite the fact that most part of the EWEC has been completed, the project is unable to form an integrated immigration and customs network from India to Vietnam. Meanwhile, the cross border issues still hinder to achieve the goal of regional connectivity to the distinct nodes of corridor. These issues are being tried to resolve by the elimination of tariff and non-tariff barriers, provision of visas and simplification of logistic services.

The NSEC is a project in progress and follows NSEC Action plan. There were 75 subsidiary projects of which 35 had been completed, 19 were ongoing and 21 were pending as of March 2015. The pending projects were mostly in rail transport, investment promotion and facilitation, and capacity building and institutional development. High business cost and the lack of standardized and harmonized border and transit trade procedures is the weakest link in the NSEC sub corridors

The Strategy and Action Plan (SAP) of SEC suggests various policy interventions that are discussed in table 3. The plan basically supports the participation of the private sector and public-private ventures to make infrastructure projects more attractive to the private sector. Therefore, the SEC authorities are more concerned towards mitigating the commercial and sovereign risks of investors. In this regard, a more genuine and encouraging business environment is important.

Despite the fact that SDC is a public-private initiative, the authorities of SDC are striving to cope with the concerns of investors. Investors require a security for their investment in long run due to an expected and uneven increase in the cost of business. Therefore, the SDC implementation authority has offered equity participation and loan funding.

The DMIC includes huge projects and processes deep impacts on multiple stakeholders. However, there is a bundle of issues with the projects as abandoned power projects, slow pace of project and weak corridor nodes. These impediments arise due to lack of consultation with elected bodies, society groups and elected bodies and weak policy structure of the corridor.

\subsection{Policy Interventions of Selected African Corridors}

The potential impediments inhibited by the TKC may hinder the corridor to transform in to economic corridor. Theses include a set social obstacle, infrastructure issues and financial impediments. Table 4 illustrates a brief view of these sets. These setbacks were addressed by the proposed dry port initiative that may facilitate in storage of goods and decrease transportation cost. It will also transit time for the transporting of the goods. These facilities can offer various benefits to the system of importing and exporting, as one can be strategically located in a border area so that it is accessible by both countries without having to undergo border processing.

\section{Table 9: Matrix of Policy Interventions of African Corridors}

\begin{tabular}{|c|c|c|}
\hline Corridor & Challenges & Policy Interventions \\
\hline $\begin{array}{l}\text { Trans } \\
\text { Kalahari } \\
\text { Corridor }\end{array}$ & $\begin{array}{l}\text { - Regional Integration } \\
\text { - Low level of business education in } \\
\text { the SME community } \\
\text { - Health and Safety Concerns } \\
\text { - Expansion of the Port of Walvis } \\
\text { Bay } \\
\text { - Road Damage from heavy } \\
\text { - Lansport } \\
\text { - Lack of economic diversification }\end{array}$ & $\begin{array}{l}\text { - Development of Cluster Projects } \\
\text { - Creation of a Dry Port System } \\
\text { - Set up of Town Capacity building } \\
\text { Program in } 2005 \text { between Namibia } \\
\text { and Zambia } \\
\text { - Promotion of alternative } \\
\text { transportation methods }\end{array}$ \\
\hline $\begin{array}{l}\text { Maputo } \\
\text { Development } \\
\text { Corridor }\end{array}$ & $\begin{array}{ll}\text { - } & \text { Negative criticism on one-stop } \\
\text { - } & \text { Cacility from discouraged workers } \\
\text { - } & \text { Corruption } \\
\text { - } & \text { Delayed service } \\
\text { - } & \text { Slow initiation pace of projects } \\
\text { - } & \text { Lack of community engagement }\end{array}$ & $\begin{array}{l}\text { - } \begin{array}{l}\text { Appointment of competent project } \\
\text { managers on both end nodes }\end{array} \\
\text { - } \quad \text { Strengthening private sector } \\
\text { involvement } \\
\text { - } \quad \text { Support to SMMEs } \\
\text { - } \\
\text { Assurance of easy access and flow of } \\
\text { goods and people between }\end{array}$ \\
\hline
\end{tabular}




\begin{tabular}{|l|l|r|}
\hline Corridor & Challenges & Policy Interventions \\
\hline $\begin{array}{l}\text { Reluctance for communities to } \\
\text { participate in the corridor } \\
\text { development }\end{array}$ & $\begin{array}{l}\text { South Africa and Mozambique } \\
\text { - Through the upgradation of Komati } \\
\text { port-Garcia Borer post }\end{array}$ \\
& $\begin{array}{l}\text { Introduction of one -stop border } \\
\text { control procedure to reduce the } \\
\text { cross-border bottlenecks }\end{array}$ \\
& $\begin{array}{l}\text { No requirement of visa for South } \\
\text { Africans to enter Mozambique }\end{array}$ \\
\hline
\end{tabular}

\section{Source: Compiled by Authors}

The MDC is regarded as a successful initiative, yet, there still exists some specified operational setbacks of the project. These include failure in providing adequate rail services, environmental concerns, investments, government issues, unsatisfactory progress and environmental issues as it is shown in table 5. Maputo corridor possesses strong PPP and the government of both countries monitors it.

It is worth mentioning that the role of African Development Bank (AfDB) is commendable as the bank is striving to use economic corridors as a strategy for regional integration under the Action Plan for the Acceleration of Industrialization. The plan underlined the promotion of economic or development corridors and other Spatial Development Initiatives (SDIs) to focus on resource based anchor investments for infrastructure interventions in association with business linkages to SMEs.

\subsection{Policy Interventions of Selected European Corridors}

Despite the fact that BAC shows impressive outcomes, the patrons of corridor are unable to cannibalize the existing business. This shows scant interest in providing new and better transport facilities. Furthermore, private sector participation is still limited. Turning to the logistics facilities, lack of mutual consent of drivers is also a major constraint. Besides this, high fuel costs due to legal constraints are also fuelling up the costs of the corridor.

Table 10. Matrix of Policy Interventions of European Corridors

\begin{tabular}{|c|c|c|}
\hline Corridor & Challenges & Policy Interventions \\
\hline $\begin{array}{l}\text { Baltic Adriatic } \\
\text { Corridor (BAC) }\end{array}$ & $\begin{array}{l}\text { - } \\
\text { Scant interest in providing new } \\
\text { - } \quad \text { Mostly state owned rail-road carriers } \\
\text { - } \quad \text { No business expansions } \\
\text { - } \quad \text { High fuel costs }\end{array}$ & $\begin{array}{l}\text { - Infrastructure modernization } \\
\text { and technical improvements } \\
\text { to comply to EU standards are } \\
\text { require }\end{array}$ \\
\hline $\begin{array}{l}\text { South East } \\
\text { Transport Axis } \\
\text { (SETA) Corridor }\end{array}$ & $\begin{array}{l}\text { - } \quad \text { Time consuming border procedures } \\
\text { - } \quad \text { Lack of the harmonization of } \\
\text { procedures } \\
\text { - } \quad \text { Lack of mutual acceptance of drivers } \\
\text { - Lack of coordination between } \\
\text { agencies and country's regulatory } \\
\text { authorities }\end{array}$ & $\begin{array}{ll}\text { - } & \text { Improved capacity by new } \\
\text { - } & \text { Sidetracks } \\
\text { - } & \text { Reduction in waiting time } \\
\text { - } & \text { Reduction in stops of } \\
\text { international trains } \\
\text { - } \quad \text { Launch of a Demo train for } \\
\text { regular connection } \\
\text { - } \quad \text { Customs clearance for } \\
\text { passenger trains } \\
\text { - Customs clearance for } \\
\text { passenger trains }\end{array}$ \\
\hline
\end{tabular}

\section{Source: Compiled by Authors}

The SETA corridor is a road-rail initiative to ensure more accessibility to other global markets and thus requires high speed transport modes. However, time consuming document procedures are the key constraints in providing competitive and fast rail connections for passengers and freight transport. Meanwhile, lack of the harmonization and coordination between authorities is also the challenge. We are interested here to figure out the challenges faced by the authorities of a corridor and how they fixed these issues. This may assess to prescribe some tangible soft policy interventions to develop a concrete analytical framework for CPEC in Pakistan.

\section{Analytical Framework for CPEC}

Since its inauguration, CPEC has been a talk of the town due to geopolitical and strategic opportunities and risks, fetters of geographical factors and restraints to economic growth projections. Therefore, the long-term plan of CPEC is announced to deal with the concerns of the relevant stakeholders.

The short-term plan of CPE includes the completion of transport an energy projects by 2020 removing the major bottlenecks restraining socio- economic development of Pakistan. Considering the medium term objectives, 
the project utilizes the infrastructure to develop the industrial set up in Pakistan. This includes completion of nine Special Economic Zones (SEZs) for balanced economic growth. It is proposed that given the accomplishment of short and medium term objectives, the project of CPEC will be completed by 2030. The long term plan of CPEC includes entire completion of the project with sustainable growth and taking CPEC further to connect with economic development of Central Asia and South Asia making the region an international economic zone.

Currently, the program is heading towards its medium term projects that are related to infrastructure, energy and connectivity. However, given the customary and institutional arrangements (bureaucratic delays, in availability of authentic information) the project does not seem to meet its targets on time.

Considering the energy targets of CPEC, in a time span of four years (2015-18) a significant contribution of CPEC is the enhancement of 10,000 megawatt energy capacity in Pakistan. This capacity is sufficient enough to overcome the chronic energy shortfalls by enhancing the plant efficiency from 28 percent to 61 percent. This would definitely bring down the cost to domestic consumers. However, this additional capacity has nothing to do for consumers, as this power capacity is not much helpful as government of Pakistan has not been able to enhance transmission and distribution capacity. Hence, distribution delays and delay in paying dues have exerted massive push on public expenditures and will further escalate subsidies in absence of institutional reforms (Cobacho, Caballero, Gonzalez, \& Molina, 2010).

The second important area is the construction sector that also includes infrastructure development and construction of new highways/motorways and railway links from Gwadar to Kashgar and the Mass Transit systems within big cities. Undoubtedly, this upgradation and rehabilitation process would provide relieve to domestic producers from high cost transportation through trucking fleet but would also facilitate the lower income group due to reduced travel time and savings in transportation expenses.

The achievement of medium term goals of CPEC includes the improvement in livehood of people along the CPEC route. It is expected that the regressive districts of Balochistan and Khyber Pakhtunkhwa (Southern) would be facilitated more by the western route of CPEC as the route will assess the community to link up with the other national markets. The benefits to these communities include increase in yield and selling of their products (mining, livestock and poultry, horticulture (mining, livestock and poultry, horticulture, fisheries ), set up of cool chains and warehousing facilities, easy processing at adjoined processing zones, access to trucking fleet and containers and installments of fibre optic networks to these deprives districts. All these benefits are attributed to the basic facilities of education, heath, drinking water, and training. However, still no project of these facilities has been initiated in Balochistan. If we associate these facilities with the establishment of industrial zones then here a question arises that how the communities would get benefit from such zones. This may create resentment that the benefits are not accruing to the people at large in these districts/geographic areas.

Nonetheless, investment in infrastructure expands the road structure in a developing economy that would assess firms to expand exports. This would surge the sales of the firms leading more jobs in the economy. However, the compliance of this proposition with reality is still unknown (Martincus, Carballo, \& Cusolito, 2017). Considering labor market prospects of CPEC, according to the recent study by CPEC Centre of Excellence, the project has the potential to generate job opportunities for I.2 million workers including various initiatives of infrastructure, energy, and industrial collaboration and Gwadar port development. The study revealed that skilled staff required for these projects include electrical and communication engineers, project managers, signal support staff, communication engineers, and civil and electrician engineers. The availability of this type of labor in the deprived areas of the project is another debate as labor from other part of the country will demand more wages and thus this would create more burdens on the cost of the projects. Some economists have also argued the benefits to local labor as they feel that most of the projects employ Chinese labor in big numbers.

Despite the fact that Pakistan is an agriculture economy, there is still an uncertainty in farmers of Pakistan for lack of information regarding that what would they have to expect from CPEC. Meanwhile, due to increased transportation links and low tariffs Chinese products are already found in Pakistani markets and competing with locally grown produce. Although, Chinese investment might be considered as remedy for some of the impediments for the agriculture sector such as water scarcity, energy shortages, and poor post-harvest infrastructure yet, no public debates have been held on CPEC in this regard.

Given the above scenario, we develop an analytical framework that takes into account the each plan of CPEC and suggests relevant soft policy interventions. Soft interventions are basically policy measures that are designed to build the capacity of the economy and require relatively more financial assistance to improve institutions and capacities (Galvez Nogales, 2014). Considering the corridors, these include multidimensional aspects such as training and development, transport facilitation, management of natural resources and so on.

In figure 2 , it is evident that initially the CPEC is a hard infrastructure intervention in short term which concurrently ensures infrastructure development. Thus, it requires a disciplined and comprehensive approach to achieve growth, competitiveness and regional development. 
Figure 2. Analytical Framework for CPEC

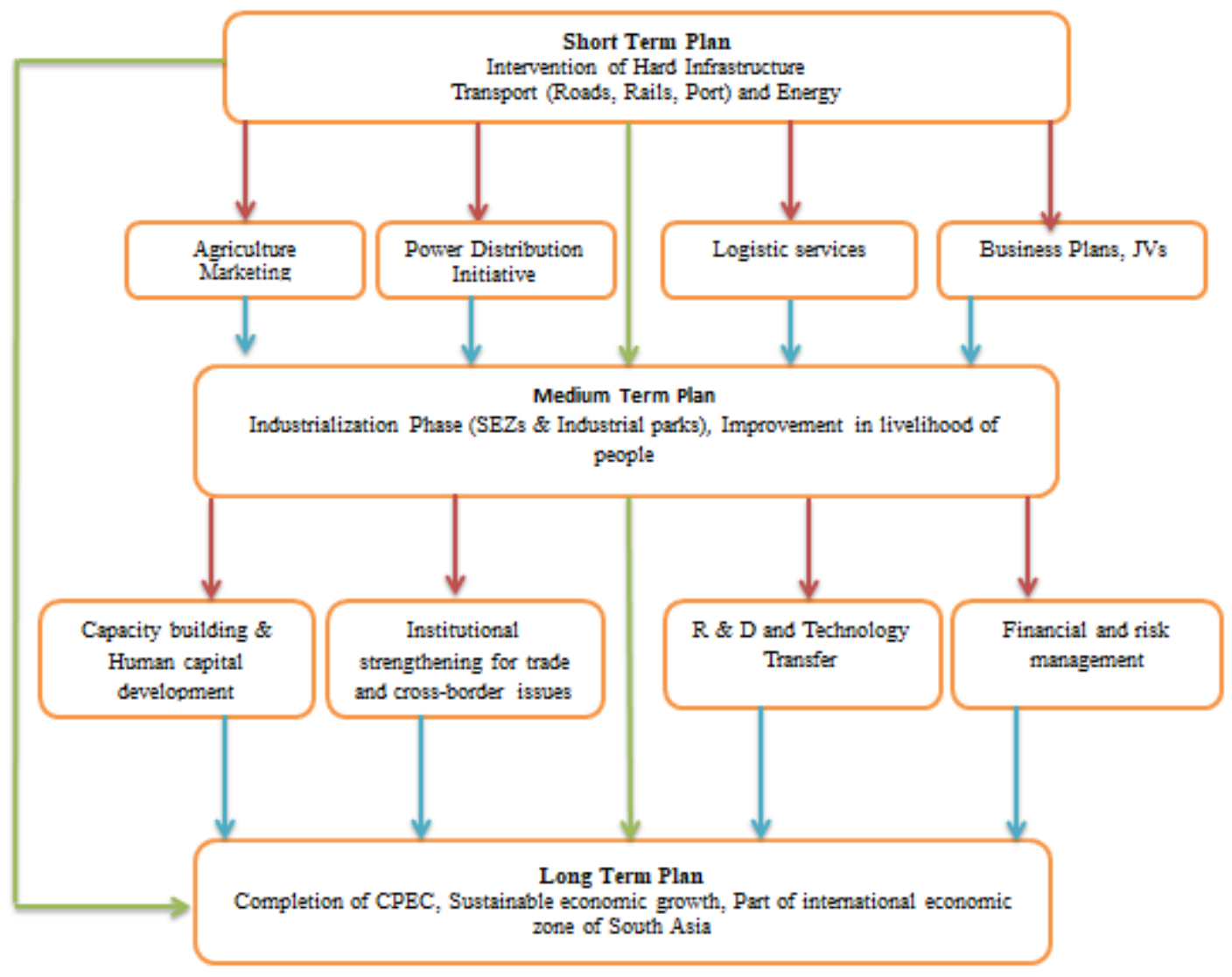

\footnotetext{
Note. $=$ Actual/Proposed Links

$\downarrow=$ Missing Links

$=$ Positive Change Enablers
}

The transport development of the corridor requires the support of logistic industry with relevant policy interventions. These include simple procedures for trade, economies of scale to support the low-cost business at global level, investments in specific logistics businesses (such as cool chain, trucking chain and warehousing) and strategic cooperation between public and private sector for new logistics solutions (Banomyomg, 2008; Banerjee, 2017; Aqeel, 2016).

Meanwhile, the distribution of power of must also be initiated to facilitate the highly affected business sector in Pakistan. At this stage, government support for domestic producers, specifically Small and medium Enterprises (SMEs) will regain the confidence of domestic producers through the provision of infrastructure, power, and a range of services and incentives in terms of business plans and Joint Ventures (JVs) with China. Agriculture is the relevant but neglected sector and a weak part of the CPEC and thus inclusion of agriculture marketing. It is expected that collaboration of these initiatives would foster the outcomes of the short period and accelerates the development of the medium-term plan.

The long-term plan of CPEC is a broader context of the national development as by the end of this stage nine SEZs in Pakistan would start functioning in Pakistan. The significance of (SEZs) is crucial for productive and efficient utilization of industry output. (Ishida, 2009) Yet, completion of these SEZs is not sufficient enough to achieve the medium-term goals. The success of these SEZs rely on the capacity building and human capital development through skills development and training program in the areas of the project as this will also benefit the derived communities along the route of CPEC. Besides this, the issue of capacity and capital deficiency can be amended through again with JVs with China (Munnell, 1992). The involvement of the business community in the project is thus highly recommended to unlock the potential of CPEC. Furthermore, as the project is supposed to be entering in its completion stage in 2030, the program will face new challenges of cross-border transactions and legal procedures.

These can be resolved by introducing institutional strengthening for trade and cross border issues and financial and risk management are required to deal with the financial dynamics between China and Pakistan. An increase in institutional competences ensures effectiveness of government policy that particularly fosters the 
development process through infrastructure development (Esfahani \& Ramírez, 2003).

According to Younis (2014), the growth outcomes of CPEC in short term and long term plans may differ. Still, CPEC is a milestone for the economy of Pakistan the problems of project stem from impervious policy interventions, lack of information and the failure of government of Pakistan to heed local and regional concerns. The long-term plan of CPEC (2017-2030) has shown no input in clearing the doubt of the public. We have also felt the plan is formulated without addressing the concerns of business community and local civil society and thus the anti-CPEC debate still goes on.

\section{Conclusion}

The analysis of global corridors highlights the fact that corridors are present in every part of world. From the advanced economic centers of Europe, China and Indian sub-confinement to the developing and less prosperous regions of the Asia Minor and sub-Saharan Africa. The international nature of these corridors underscores their importance to regional trade integration.

Moreover, the analysis of global corridors provides useful insights for this study. First, the analysis of these corridors ended up on a conclusion that all corridors intend to transform in to an economic corridor. Second, the completion of corridor does not ensure economic development and regional integration due to divergent national and cross border bottlenecks that vary from region to region (Esteban, 2016). Third, these case studies are helpful in formulating an analytical framework for CPEC to provide some practical policy interventions for the success of CPEC.

$\mathrm{CPEC}$ is a journey towards industrialization and economic regionalization in the globalized world following peace, progress and win-win approach. Considering the economic implications of CPEC it will lead to infrastructure development, job creation, increase in business opportunities with trade facilitation and recommencement of economic growth. Pakistan is required to address major bottlenecks to sustain its credibility to China and meanwhile to people of Pakistan for growth momentum of the project. A well synchronization and timely completion of projects of infrastructure, energy may assess to reduce the governance and administration paucities. The unhinged socio-economic development and external sector susceptibilities also need to be monitored to avoid any possible challenges to CPEC.

Additionally, each stage of CPEC requires divergent policy interventions. The core element of these interventions is to bring the relevant policy at the right time. CPEC will foster economic activities along a transport a route with holistic and multisectoral approach.

Economic corridor stimulates regional integration and trade and it is indeed a common tool for development, yet, when it fails to produce the proposed economic benefits, it would be then considered as an unbalanced investment (Melecky, 2017). Hence, the improvements in infrastructure arrangements in Pakistan require a harmonized customs measures and regulatory module of other involved authorities (Vaqar \& Ghulam, 2011).

\section{References}

Abid, M., \& Ashfaq, A. (2015). CPEC: Challenges and opportunities for Pakistan. Journal of Pakistan Vision, $16(2), 142-169$

Ahmed, V., \& Ghulam, S. (2011). Trade facilitation for economic corridors in South Asia: the perspective of Pakistan. University Library of Munich, Germany.

Aqeel, M. U. H. A. M. M. A. D. (2016). Impact of China Pakistan Economic Corridor (Unpublished degree thesis, BBA International Business). ARCADA.

Asian Development Bank. (2015). Connecting South Asia and Southeast Asia. Retrieved from https://www.adb.org/publications/connecting-south-asia-and-southeast-asia.

Banerjee, P. (2017). Development of East Coast Economic Corridor and Vizag-Chennai Industrial Corridor: Critical Issues of Connectivity and Logistics. Retrieved from https://www.adb.org.

Banomyong, R. (2008). Logistics Development in the North-South Economic Corridor of the Greater Mekong Subregion. Journal of GMS Development Studies, Vol. 4, pp. 43-57.

Bhattacharyay, B. (2010). Estimating Demand for Infrastructure in Energy, Transport, Telecommunications, Water, and Sanitation in Asia and the Pacific: 2010-2020.

Bhattacharyay, B.N. (2010). Infrastructure for ASEAN connectivity and integration. ASEAN Economic Bulletin, $27(2), 200-220$.

Brunner, H. P. (2013). What Is Economic Corridor Development and What Can It Achieve in Asia's Subregions?. Retrieved from https://www.adb.org.

Butt, K. M., \& Butt, A. A. (2015). Impact of CPEC on Regional and Extra-Regional Actors. The Journal of Political Science, 33, 23.

Cobacho, B., Caballero, R., González, M., \& Molina, J. (2010). Planning federal public investment in Mexico using multiobjective decision making. Journal of the Operational Research Society, 61(9), 1328-1339.

Coşar, A. K., \& Demir, B. (2016). Domestic road infrastructure and international trade: Evidence from Turkey. 
Journal of Development Economics, 118, 232-244.

De, P., \& Iyengar, K. (2014). Developing economic corridors in South Asia. Retrieved from https://www.adb.org.

Esfahani, H. S., \& Ramírez, M. T. (2003). Institutions, infrastructure, and economic growth. Journal of development Economics, 70(2), 443-477.

Esteban, M. (2016). The China-Pakistan Corridor: a transit, economic or development corridor. Strategic Studies, $36(2), 63-74$.

Galvez Nogales, E. (2014). Making economic corridors work for the agricultural sector. Agribusiness and Food Industries Series No. 4. FAO, Rome.

Hope, A., \& Cox, J. (2015). Development Corridors. Coffey International Development. Retrieved from https://assets.publishing.service.gov.uk.

Ishida, M. (2009). Special economic zones and economic corridors. ERIA Discussion Paper Series, 16, 2009. Retrieved from http://www.eria.org/publications.

Martín, J. C. (2011). Transportation changes in Europe. Transportation Journal, 50(1), 109-124.

Martincus, C. V., Carballo, J., \& Cusolito, A. (2017). Roads, exports and employment: Evidence from a developing country. Journal of Development Economics, 125, 21-39.

Melecky, M. (2017). Appraisal econometrics for proposed transport corridors: optimal placement, intervention design, and wider economic benefits. Retrieved from https://elibrary.worldbank.org.

Miller, D. T. (2017). The China Pakistan Economic Corridor: Indicator of Chinese Strategic Energy Goals and a Challenge to the Open Procurement Status Quo. Jackson School of International Studies. University of Washington, Seattle Washington. Retrieved from https://web.isanet.org.

Mulenga, G. (2013). Developing economic corridors in Africa: Rationale for the participation of the African Development Bank. NEPAD, Regional Integration and Trade Department, (1).

Munnell, A. H. (1992). Policy watch: infrastructure investment and economic growth. Journal of economic perspectives, 6(4), 189-198.

Official website of China Pakistan Economic Corridor. (2018).Retrieved from http://cpec.gov.pk/.

Roberts, M., Melecky, M., Bougna, T., \& Xu, Y. (2018). Transport corridors and their wider economic benefits: a critical review of the literature. Retrieved from http://documents.worldbank.org.

Terrill, M. (2018). Reforming transport planning in Australia. Road pricing and provision, 47.

Wendt, J. A., \& Wiskulski, T. (2012). Baltic-Adriatic corridor and cooperation. Cross-border cooperation and local development in Poland and Romania, pp.75-88.

Younis, F. (2014). Significance of Infrastructure Investment for Economic Growth. Retrieved from https://mpra.ub.uni-muenchen.de. 